\title{
Intelligence Profile in Deliquent Adolescent (Study on Deliquent Adolescents in Correctional Institution for Male Children- Tangerang)
}

\author{
Naomi Soetikno* \\ Faculty of Psychology, \\ Tarumanagara University
}

\author{
Stella Tirta \\ Faculty of Psychology, \\ Tarumanagara University
}

*Corresponding author: naomis@ fpsi.untar.ac.id

\begin{abstract}
Violence perpetrated by adolescents is very related with youth psychological conditions, one of which is intelligence aspect. Intelligence is an individual potency to be able to resolve problems logically, directed, and using ways that can be accepted by the environment. Through this study, we want to get the profile of the intelligence of juvenile perpetrators of violence who are now in correctional institution. The benefit of this study is to give an informations for parents and teachers to provide an appropriate parenting and education. This is a qualitatively study from four adolescent participants who commited violent crimes, aged 15-18 years, and they are residents of correctional institution for male children in Tangerang. Participants Intelligence was evaluated using Wechsler Intelligence Scale for Children (WISC) or Wechsler Belleveu (WB), and followed with interview of all participants. The study was conducted in February 2013 to May 2013. The Results show the full IQ scores of participants were in the category of Borderline Intellectual Functioning, with performance skills grew significantly than verbal skills. The Additional data about the participants was the participants were grew up in the families, which the parenting style of the parents or signficant persons accompanied by violence.
\end{abstract}

Keywords: intelligence, violence, youth

\begin{abstract}
Abstrak
Kekerasan yang dilakukan oleh remaja sangat berkaitan dengan kondisi psikologis dari mereka yang salah satunya adalah kecerdasannya. Kecerdasan merupakan suatu potensi yang dimiliki oleh tiap individu untuk dapat menyelesaikan persoalan secara logis, terarah, dan dapat diterima oleh lingkungan. Dalam penelitian ini ingin diketahui profil kecerdasan dari remaja pelaku tindak kekerasan yang berada di lembaga pemasyarakatan. Manfaat dari penelitian ini berguna untuk memberi informasi kepada orangtua dan guru sehingga dapat memberikan pola pengasuhan dan pendidikan yang tepat. Ini merupakan penelitian kualitatif pada empat orang partisipan penelitian dengan latar belakang kasus pidana adalah tindak kekerasan, berusia 15-18 tahun, dan berada di lembaga pemasyarakatan anak pria di Tangerang. Pemeriksaan dengan tes kecerdasan Wechsler Intelligence Scale for Children (WISC) atau Wechsler Belleveu (WB) serta anamnesa terhadap partisipan. Penelitian dilakukan pada bulan Februari 2013 sampai dengan Mei 2013. Hasil dari penelitian ini adalah bahwa dari keempat partisipan didapat angka kecerdasan berada pada kategori Borderline Intellectual Functioning dan dengan kemampuan performance berkembang signifikan dari kemampuan verbal. Data tambahan diketahui bahwa latar belakang pengasuhan dalam keluarga dari partisipan disertai dengan kekerasan.
\end{abstract}

Kata kunci: kecerdasan, kekerasan, remaja 


\section{Introduction}

Throughout their development, children will learn many things in life. They could learn about positive things, such as prosocial behavior and friendship, and they could also learn about negative things, such as violent or aggressive behavior. Violence is a behaviors that attempt or is intended to threaten, or harm other people (Berns, 2007). According to The Central Agency of Statistics Republic of Indonesia (2010), there is an increasing number of youth violence cases nationally. There was approximately 3.100 youth involved in juvenile crime cases in 2007, and the number increased to 3.300 youth in 2008 and 4.200 youth in 2008. The high rates of juvenile crime showed that the crime committed by adolescent is one of the most serious problems within society. Some forms of violence that conducted by these children and adolescents include murder, rape robbery and assault. Children and adolescent learn about violent behavior in many ways. Through violent programs on television or other media, and by seeing the behaviors of parents, caregivers, peer, or even other adults who are not in a close relation with the adolescents, all of these might become a model for children to imitate and learn violent behavior. According to Bandura (in Berns, 2007), through a series of experiences a child will learn about when the right thing to act violent and to whom violence can be directed. Berns (2007) said that children will imitate what is done by role models, such as parents and peers. Research conducted by Bandura, Ross and Ross (in Berns, 2007) also proved that children can learn violence from other adults who act violent behavior. According to Elders (in Berns, 2007), many people believed when children was exposed to violence issue in their neighborhood and through the media, they might perceive that violence is an acceptable way and also is an effective way to solve the problem. Loeber (in Latzman, 2009) also explained that children's violent behavior could be a result of peers' rejection, school problems, difficulties in accommodating demands from parents and teachers, and also the result of adjustment difficulties toward laws and regulations in society.

Research about Intellectual functioning and aggression by Huesmann, Eron, \& Yarmel (1987), that was conducted on 600 subjects of both parents and children, showed that aggression in childhood will influence the development of intellectual functioning and predict the poor performance of intelligence in adulthood. Adolescence with aggression shows poor school motivation and information-processing abnormalities (Raine et al, 2006). Research finding on how children perceived their environment that later influenced their aggressive behaviors, showed that aggressive children had difficulties in judging social cues. Even though they tend to have a core moral values about intentionally harming others is not right / fair, but they have a weak social reasoning in determining whether others have violated those moral values or not (Arsenio et al, 2009).

There is a lot of researches on the development of aggressive behavior that became a characteristic of psychopathy, and one of the study was conducted by Vitale et al (2005, in Salekin \& Frick 2005) which explained thinking mechanism that potentially affecting psychopathy characteristic is a thought process that result from socialization. Vitale et al explains how people learn and effectively apply the rules that are acceptable in the social environment. People who have the characteristics of psychopathy has a level low level of anxiety, passive learning process, and have lower ability in spatial aspect. 
How individuals deal with problems and whether the behavior was acceptable by environment are strongly influenced by the intelligence of the individuals. According to Wechsler (in Sattler 2001), he stated that "intelligence consists of qualitatively different abilities... intelligence is the aggregate or global capacities of individual to act purposefully, to think rationally and to deal effectively with his environment". Intelligence that measured by the standardization adjusted to people in general is called the index of intelligence, and referred to as the Intelligence Quotient (IQ), which is the ratio of mental age to chronological age (Sattler, 2001). A similar concept of intelligence was expressed by Boeree (2003) that intelligence is a person's capacity to acquire knowledge, apply knowledge and engage in abstract reasoning (in Ijaz, Kazmi, \& Nazir, 2013).

Intelligence develops in line with the result of the interaction of individuals with the existing culture around him throughout his life. On examination of intelligence by using the Wechsler scale made in America, it was found that the standard norms used in other countries such as South Africa were far below the norm (Wyhe, 2012). It indicates that the intelligence related to culture. Other researchers from Pakistan also found that culture affected the intelligence. The research results indicated urban male students had higher score on non-verbal intelligence than rural male students, similarly urban female students comparatively had higher score than rural female students (Ijaz, Kazmi, \& Nazir, 2013). Because culture aspect influences a person's intelligence, so the condition of juvenile perpetrator with violence cases in Indonesia may have their own characteristics. There are important explanations can be given in understanding the aspect of intelligence in violent behavior or criminality. Crime is related to the low level of intelligence (IQ), even though the effect is indirect, which then leads to lower school and work performance, and limited adjustment and socialization (Herrnstein \& Murray, 1994; Magdol, Moffitt, Caspi, \& Silva, 1998; Ward \& Tittle 1994 in Guay, Oiumet, and Proulx, 2005). Antisocial tendency lifestyles often associated with alcohol and drugs abuse, accidents, and discontinue education, any of which could adversely affect individual cognitive abilities that measured by intelligence tests (Moffitt, Gabrielli, Mednick, \& Schulsinger 1981 in Mottus, Gulkakev, Allik, Lanidra \& Pullmann, 2011). Regarding the relation between level of intelligence with crime was described later by Cusson (1998 in Guay et al , 2005), which is low level of intelligence causing criminal offenders do not have an adequate understanding of how to anticipate the consequences of their actions on others.

Research results obtained through the examination of intelligence using the Wechsler Intelligence Scales for Children-Revised (WISC-R) by Brennan et al (2003) showed that adolescents aged 17 years old who have aggressive behavior problems had vocabulary, information, arithmatic, and similarities subtests scores that was similar with the results of children aged 5 to 15. Research conducted by Moshkani, Afooz, and Arjmandnia (2015) indicated that there were significant differences between adolescents who deliquent and adolescents in general (non-deliquent adolescents), where generally non-deliquent adolescent have a higher level of intelligence. . The importance of cognitive abilities that can prevent the emergence of aggressive behavior also explained by McGloin (in Sujoko, 2011) In-depth investigation showed that deliquent adolescent have a lower level of verbal intelligence compared to their performance intelligence (Leeman \& Henry in Moshkani, Afooz \& Arjmandnia, 2015). Cognitive limitations on the perpetrators of violence are also shown by the neuropsychological examination. 
These cognitive limitations are related to malnutrition, fetal alcohol syndrome, neglection, traumatic brain injuries, and genetic fragility, as it is described in several studies of Bennet, Bendersky, \& Lewis, 2008; Brennan Hall, Bor, Najman, \& Williams, 2003).

Based on the explanation of the relationship between aggression and intelligence, howindividual intelligence has several developing aspects to support general mental ability, also because of limited researchers regarding the intelligence of juvenile perpetrator who commit acts of violence in Indonesia, so the purpose of this study is to get more deeper understanding about cognitive aspects on juvenile perpetrators of violence, especially their intelligence profile.

\section{Methods}

Participants in this study were four juvenile perpetrators of violence who are now are residents of correctional institution for male children in Tangerang (Lembaga Pemasyarakatan Anak Pria Tangerang). Characteristics of the participants are they are at adolescence period, male, and in the age 15 to 18 years old.

This study used descriptive method by defining the test results and elaborating it with participant semi-structured interview results. Data collection was done individually for each participants from February 2013 to May 2013.

Research instruments in this study are Wechsler Intelligence Scale tests, that are Wechsler Intelligence Scale for Children-revised (WISC-R) for participants under the age of 16 years old and Wechsler-Bellevue Intelligence Scale (WB) for participants over 16 years old. Wechsler scale, that commonly used to obtain the level of intelligence, was divided into two major groups of ability, which are the ability of verbal intelligence (VIQ) and the ability of non-verbal intelligence or performance intelligence (PIQ). the Measurement of intelligence score in this study was using Wechsler Intelligance Scale for Children(WISC) created by David Wechsler (1974), which are divided into 12 subtests and are grouped into two categories: verbal scale and performance scale, as the table below:

Table 1. Scales in Wechsler Intelligence test.

\begin{tabular}{ll}
\hline SCALE VERBAL & SCALE PERFORMANCE \\
\hline 1. Information & 1. Picture Completion \\
2. Comprehention & 2. Picture Arrangement \\
3. Arithmetic & 3. Block Design \\
4. Similarites & 4. Object Assembly \\
5.Vocabulary & 5. Digit Symbol \\
6.Digit Span & 6. Mazes \\
\hline
\end{tabular}

Scoring on WISC test was based on the correct answers and the time required by subjects in giving the correct answers. The Scores then converted into standard scores through norms and eventually will obtain an IQ score for verbal scale, an IQ score to performance scale and full IQ score. 
Table 2. The Classification of Intelligence based on the Wechsler scale.

\begin{tabular}{ll}
\hline Intelligence score & Classification \\
\hline$\geq 128$ & Very superior \\
$120-127$ & Superior \\
$111-119$ & Bright Normal / High average \\
$91-110$ & Average \\
$80-90$ & Dull Normal / Low average \\
$66-79$ & Borderline \\
$\leq 65$ & Mentally defective \\
\hline
\end{tabular}

Wechsler Intelligence Test is an individual test, which is given and answered verbally. The basis of measurement in this test is the IQ deviation with mean value 100 and the standard deviation is 15. Standard scores in Wechsler intelligence test was ranged between $0-18$, with the average category is $8-12$ (Sattler, 2001).

\section{Results}

The Following is the identity descriptions of the four participants in this study are $\mathrm{D}, \mathrm{E}, \mathrm{F}$, and $\mathrm{Fa} . \mathrm{D}$ is a male adolescent aged 16 years and 10 months, who was the second child of three and currently his education is in high school grade 1. Both of D's parent had high school education backgrounds.

Table 3. Comparison of participants 's characteristic and family characteristic :

\begin{tabular}{|c|c|c|c|c|}
\hline & $\mathrm{D}$ & $\mathrm{E}$ & $\mathrm{F}$ & $\mathrm{Fa}$ \\
\hline Age & $\begin{array}{l}16 \text { years } \\
10 \text { months }\end{array}$ & $\begin{array}{l}16 \text { years } \\
8 \text { months }\end{array}$ & $\begin{array}{l}16 \text { years } \\
11 \text { months }\end{array}$ & $\begin{array}{l}16 \text { years } \\
6 \text { months }\end{array}$ \\
\hline $\begin{array}{l}\text { Participants' } \\
\text { level of } \\
\text { education }\end{array}$ & $\begin{array}{l}\text { High School } \\
\text { grade } 1\end{array}$ & High School grade 3 & $\begin{array}{ll}\begin{array}{l}\text { High } \\
\text { grade } 2\end{array} & \text { School }\end{array}$ & High School grade 1 \\
\hline Child birth order & $\begin{array}{l}\text { Middle child } \\
\left(2^{\text {nd }} \text { of } 3\right. \\
\text { childs })\end{array}$ & Only child & $\begin{array}{l}\text { Last child } \\
\text { ( } 7^{\text {th }} \text { of } 7 \text { childs) }\end{array}$ & $\begin{array}{l}\text { First child } \\
\left.\text { ( } 1^{\text {st }} \text { of } 2 \text { childs }\right)\end{array}$ \\
\hline Type of crime & $\begin{array}{l}\text { premeditated } \\
\text { murder }\end{array}$ & $\begin{array}{l}\text { gang street fighting } \\
\text { case }\end{array}$ & $\begin{array}{l}\text { underage rape } \\
\text { cases }\end{array}$ & premeditated murder \\
\hline $\begin{array}{ll}\text { Duration } & \text { of } \\
\text { punishment }\end{array}$ & 7 years & 3 years and 6 months & $\begin{array}{l}3 \text { years and } 2 \\
\text { months }\end{array}$ & $\begin{array}{l}8 \text { years and } 6 \\
\text { months }\end{array}$ \\
\hline $\begin{array}{l}\text { Parents' level of } \\
\text { education } \\
\text { Father } \\
\text { Mother }\end{array}$ & $\begin{array}{l}\text {-High School } \\
\text {-High School }\end{array}$ & $\begin{array}{l}\text { - High School } \\
\text { - Jr High School }\end{array}$ & $\begin{array}{l}\text { - Jr High School } \\
\text { - Primary School }\end{array}$ & $\begin{array}{l}\text { - Jr High School } \\
\text { - Jr High School }\end{array}$ \\
\hline $\begin{array}{l}\text { Social economic } \\
\text { Status }\end{array}$ & $\begin{array}{l}\text { Middle-low } \\
\text { economic level }\end{array}$ & $\begin{array}{l}\text { Middle } \\
\text { level }\end{array}$ & $\begin{array}{l}\text { Low economic } \\
\text { level }\end{array}$ & $\begin{array}{l}\text { Middle-low } \\
\text { economic level }\end{array}$ \\
\hline $\begin{array}{c}\text { Parenting Style } \\
\text { Father } \\
\text { Mother }\end{array}$ & $\begin{array}{l}\text { Authoritarian } \\
\text { and } \\
\text { accompanied } \\
\text { by violence }\end{array}$ & $\begin{array}{l}\text { Neglect; } \\
\text { Authoritative }\end{array}$ & $\begin{array}{l}\text { Authoritarian } \\
\text { and accompanied } \\
\text { by violence }\end{array}$ & $\begin{array}{l}\text { Authoritarian } \\
\text { neglected }\end{array}$ \\
\hline
\end{tabular}


His father works as an employee of PLN (national electrical company) and his mother is fulltime mother at home. The parenting style of the father and mother was involving physical punishment like hitting $\mathrm{D}$ and not gave any explanation or an apology to D. D was arrested due to acts of premeditated murder with a sentence of 7 years punishsment.

$\mathrm{E}$ is a male adolescent aged 16 years and 8 months, the sole child in the family, and currently his education is in high school grade 3 . The education background of E's father was high school level, while his mother was junior high school level. His father works as an entrepreneur and his mother is fulltime mother at home. Although E's Father didn't involve in child rearing, E's mother had a close relationship with E . E was arrested because of gang street fighting case with a sentence of 3 years and 6 months punishment.

Below is the results of intelligence examination of the four participants using Wechsler Intelligence Test, that shows the level of intelligence as well as the profile of the subtests.

Table 4. Comparison of intelligence test results of the four participants :

\begin{tabular}{lllll}
\hline \begin{tabular}{l} 
Intelligence level and $\begin{array}{l}\text { Scaled Score } \\
\text { aspect of Thinking }\end{array}$ \\
\cline { 2 - 5 }
\end{tabular} & $\mathrm{D}$ & $\mathrm{E}$ & $\mathrm{F}$ & $\mathrm{Fa}$ \\
\hline Intelligence level & $\mathrm{FIQ}=72$ & 79 & 75 & 79 \\
& $\mathrm{VIQ}=75$ & 71 & 68 & 69 \\
& $\mathrm{PIQ}=76$ & 92 & 87 & 91 \\
\hline Verbal Area & 3 & & & \\
Information & 3 & 4 & 5 & 4 \\
Comprehension & 6 & 8 & 6 & 5 \\
Digit Span & 7 & 0 & 4 & 4 \\
Arithmatic & 6 & 5 & 5 & 6 \\
Similarity & 4 & 9 & 4 & 4 \\
Vocabulary & 6 & 3 & 12 & 5 \\
\hline Performance Area & & 7 & 5 & 8 \\
Picture Completion & 7 & 6 & 7 & 4 \\
Picture & 0 & 8 & 8 & 11 \\
Arrangegement & 11 & 12 & 10 & 11 \\
Block Design & 10 & 12 & & 10 \\
Object Assembly & 6 & & & \\
Digit Symbol & & & & \\
\hline
\end{tabular}

$\mathrm{F}$ is a male adolescent aged 16 and 11 months, the seventh child of seven, and currently his education is in high school grade 2. The education background of F's father was junior high school level, while his mother was primary school level background. The father's job is a driver and his father have been married 2 times before. Meanwhile the mother is a fulltime mother at home and only married once. Both F's parent have the same authoritarian parenting style, that controled $\mathrm{F}$ and also accompanied by threats and sometimes hits when $\mathrm{F}$ behaved disobedient. $\mathrm{F}$ also monitored by his brothers, and only his sixth brother can discussed properly with F. F was arrested due to acts of underage rape cases with the length of sentence was 3 years and 2 months punishments. 
Fa is male adolescent aged 16 and 6 months, the first child of two, and currently his education is in high school grade 1. Both of Fa's parent had junior high school education backgrounds. His father works as an entrepreneur in farming and his mother is fulltime mother at home. His parent already divorced when $\mathrm{Fa}$ was fifth grade student. Since his parent divorce, Fa was lived in religious dormitory while his sister lived with their mother. The father raising Fa using authoritarian parenting style, and after the divorce the father became neglect to $\mathrm{Fa}$, while the mother was often act submissive to the rule of the father. Fa was arrested due to acts of premeditated murder with a sentence of 8 years and 6 months.

\section{Discussion}

From the data of the four participants, we find the same results regarding the level of intelligence which overall is in the category of Borderline of Intellectual level, which means that the participants' abilities to understand and to solve problem are below the average adolescents abilities level. At this stage, adolescents begin to develop the abstract thinking ability. This capability provides a new and more flexible ways for them to process the information. Understanding and ability to process information is no longer limited by the here and now concepts. These conditions are not found in the participants. The participants' ability to process information is still in concrete thinking level, that equivalent level to children aged 6 to 12 years old. Researches on intelligence and aggressivity also explained that aggressivity usually associated with low intelligence level (Mottus, Gulkakev, Allik, Lanidra \& Pullmann, 2011; Moshkani, Afooz \& Arjmandnia, $2015^{1}$; Moshkani, Afooz \& Arjmandnia, $2015^{2}$ ).

The specific finding from the four participants is they all have higher performance intelligence (PIQ) or non-verbal IQ than verbal intelligence (VIQ). This result is in line with Guay, Ouimet, \& Proulx (2005) that explained there was a mental imbalance in non-sexual violent criminals, higher on performance score than on verbal IQ. According to Ogdon (1996), who compiled the studies of intelligence measurement using the Wechsler Intelligence Scale, if the performance intelligence significantly above the verbal intelligence, it can indicate delinquent problems up to development of sociopath, and also the tendency of someone who has poor reading ability, or may be describe as doer and not a thinker. Another consideration is the social and cultural aspects that less emphasize on verbal stimulus, so the verbal skills that was needed to respond appropriately is not well developed. Aside from the quite enough large range between performance intelligence and verbal intelligence, it might come from individuals pathological conditions, which can be related to the implications of diagnostics implications, such as acting-out behavior, or psychopathy approach which is dominated by impulsive behavior. If the difference range between the two intelligence was very large and unusual, then it can be a sign of disorder on the individuals, such as the psychopath process, organic disorder, or an obstacle to development or maturation. From reviewing the dominant aspects of intelligence from all four participants, we can see that Object Assembly subtest is in average level dan considered dominant among any other subtests.

Wechsler (1954) explained that the Object Assembly was a subtest, which measure the individual's ability to solve problems inductive, draw conclusions, ability to organize practically, visual motor ability, and if accompanied by quick execution time 
with good quality result then it can be said that there is creativity in solving problems. According to Sattler and Saklofske (in Sattler, 2001), Object Assembly was a subtest which primarily measures the ability to synthesize the concrete parts into a meaningful unity, and requires visual motor coordination. This subtest is also a subtest that measures the ability to organize visually, that required constructive capabilities, as well as the ability to perceive something. In addition, object assembly is also associated with speed and precision in execution, perseverance, and long-term memory. By referring to the dominant score on Object Assembly subtest, it can be considered that the four participants who had backgrounds as perpetrators of violence, they have the ability to think inductively and they can be creative in solving problems. There are two other subtests that almost all participants have a standard score, which are in average level. They are Block Design subtest and Digit Symbol subtest. Wechsler (1954) explains that from the whole subtests on Wechsler Intelligence Scale, the subtest that have the fundamental thinking skills, or "G" factor is the Block Design subtest. It means that the individual's ability to perform tasks in Block Design subtest not requires academic learning process. The execution of the block design subtest requires an individual's ability to analyze and synthesize, non-verbal reasoning, perceptually organization, spatial visualization and conceptualization of abstract things (Sattler \& Saklofske in Sattler, 2001). From this finding, it can be said that basically the four participants have average level of capabilities to solve problem using practical analysis. Wechsler in Sattler (2001) describes the Digit Symbol as subtest that describe the willingness to learn something new and it involves speed and accuracy in the motor-visual coordination, attention, short-term memory, agility of thinking, and also the motivation. With the dominant scores on the Digit Symbol, this is means that in general the participants have the ability to learn new things that related to visual-motor coordination.

The four participants overall had a low score in some subtests that was below of average standard score, they are Information, Digit Span, Arithmetic, Vocabulary, and Picture Arrangement subtests. The results of this study is almost similar to research conducted by Brennan et al (2003) which showed a low score on the Vocabulary, Information, Arithmetic, and Similarities subtests.

Information was the first given subtest on Wechsler intelligence scale. This subtest was used to found out the commonly understood knowledges by persons of his age, and describe the broad knowledge, sensitivity to the environment, cultural background, and attitudes toward school (Sattler, 2001). Low score on digit span and arithmetic subtests described by Ogdon (1996) as limitations in attention span and concentration. Limitation in attention span and the information can cause bias in interpreted the information from environment, this result is in line with Brugman et al (2014) that there was a stronger attention bias for aggressive words that can predict reactive aggressive behavior.

Vocabulary is the ability to learn, collect information, richness of ideas, memory, ability to formulate concepts and language development (Ogdon, 1996; Sattler \& Saklofske in Sattler, 2001). The low score on vocabulary subtests indicates limites words knowledge, the lack of verbal understanding, low level of verbal skills and language development, limited education background, difficulties in verbalization or home environments where verbalizing in children was less emphasized (Sattler \& Saklofske in Sattler, 2001). Limitation at this aspect explains the difficulties of the 
participants to express their thoughts verbally and possible to have a misunderstanding. And in general, low verbal ability was indicate the lack of interest in learning from the participants and a lack of perseverance to get academic achievement.

Vocabulary is the ability to learn, collect information, richness of ideas, memory, ability to formulate concepts and language development (Ogdon, 1996; Sattler $\&$ Saklofske in Sattler, 2001). The low scores on vocabulary subtests indicates limites words knowledge, the lack of verbal understanding, low level of verbal skills and language development, limited education background, difficulties in verbalization or home environments where verbalizing in children was less emphasized (Sattler \& Saklofske in Sattler, 2001). Limitation at this aspect explains the difficulties of the participants to express their thoughts verbally and possible to have a misunderstanding. And in general, low verbal ability was indicate the lack of interest in learning from the participants and a lack of perseverance to get academic achievement.

All participants have low scores on Arithmetic subtest Arithmetic capability relates to the concentration and calculation (Sattler, 2001). Arithmetic is a mathematical abilities, associated with how individuals mathematically account the advantages and disadvantages of their behavior. This description may give the explanation why adolescents with crime cases have limitations in calculating his actions. Limitations of math skills on the perpetrators of violence are also discussed in Liu (2011).

The subtest on performance scale that got the low score in all four participants is Picture Arrangement. This subtest was described as the ability to understand and evaluate the situation in general, the ability of planning and anticipating the consequences of behaviors, and also understanding social situations (Sattler, 2001). Through this subtest, we can see how the individual's ability to pay attention to detail, alertness, ability to make plans, as well as sorting visually. Low score on this subtest indicated the limited ability of the participants to make plans in order to resolve the problems, and they do not have the anticipation and understanding of social situations.

On the Similarity subtest, nearly all participants also have a low score. Similarity is the ability of the association, looked at the relationship of one thing to another (Sattler, 2001). In adolescents with criminal case, they was indicated by lackingthis ability. The ability of the association was developed since people learn many things from their environment; learn from experience and from the acquired information. Behavior with the result of associating experience makes people can choose which subject is right or not. People with low ability of the association shows the difficulties to learn from experience.

Adolescents with a criminal case have difficultiesto look out for the relation of the information obtained previously with a plan that will be done. This condition is different from the theories of adolescent development that in this age teens develop associative thinking skills-hypothetical. Adolescents able to think about alternatives or possibilities that can occur in one situation, no longer think like in the previous stage. They are also able to make predictions on various possibilities and they can develop and test the hypothesis. People at the formal operation stage can integrate what they have learned in the past with the challenges of the future, and also make plans for the future. Sometimes limitation in information processing can cause more biases when they interpret environment cues, according to Stickle, Kirkpatrick, \& Bursh (2009) and biased social information processing associated with vulnerability towards the development of aggressive and anti-social behavior. Social information processing is a 
series of stages that occur before a person responding to social situations (Crick and Dodge in Castro, 2004). When people can't pass through these stages properly it will appear undesirable response, such response may take the form of aggressive behavior. Reactive aggression is a form of error that occurs in individual's social information processing individuals, these errors occur at the stage of encoding and attribution which are the two initial stages before heading to the other stages (Castro, 2004).

Another explanation about the violent behavior of the participants is it can also affected by parenting style that they experienced, in which in general the parents of the participants used parenting styles that accompanied by violence acts to their children. The involvement of parents in cases of violence and aggression such as parenting style, divorce, parental antisocial behavior, maltreatment in children, mothers at a young age, smoking during pregnancy, and also the genetic basis results found that both environmental and genetic influences on antisocial behavior and aggressiveness (Berns, 2007; Murtiyani, 2011; Sujoko, 2011).

\section{Conclusion and Suggestion}

\section{Conclusion}

Results from this study of the intelligence on all four participants, who was male juvenile perpetrators of violence and currently are residents of correctional institution for male children in Tangerang, showed that the level of intelligence that functions on all the four participants are Borderline Intellectual. It explains the limitations of their ability to solve problems. From their potential intelligence, we know that the participants have better performance abiltity than verbal abilities, they use more practical ways in problem-solving without better consideration of the information. Subtests that dominant and are in the average standard score category is Object Assembly subtest, followed by the Block Design subtest and Digit Symbol subtest. The participants have several underdeveloped abilities, that was shown in low standard scores in Information subtest, Digit Span subtest, Arithmetic subtest, Vocabulary subtest, and Picture Arrangement subtest. This Low standard scores is related to the participants' limitations to anticipate situations in the social environments, so that violent behavior that they commited is caused by lack of planning ability and the ability to solve social problems. The ability that developed on participants is the ability to solve problems in their own ways.

\section{Suggestion}

Suggestion from this study was given primarily to the parents about parenting styles, in which disciplinary attitude that accompanied by threats and physical punishement should be avoided. Suggestion also given to teachers, so that they can understand the condition of adolescents who have emotional problems and in the phase of identity searching. We expect more teachers will give adolescents the opportunity to discuss about the things that they interest and given a wider interesting knowledge. This study is expected to be enhanced by adding bigger number of participants, so the quantitative calculation would be able to describe more clearly the differences on juvenile perpetrators of violence behavior's subtests in intelligence tests. 


\section{Reference}

Arsenio, W. F., E. Adams, \& J. Gold. (2009). Social information processing, moral reasoning and emotion attributions: Relations with adolescents' reactive and proactive aggression. Child Development, 80(6), 1739-1755.

Berns, R.M. (2007). Child, family, school, community socialization and support $\left(7^{\text {th }}\right.$ ed.). California: Thomson Wadsworth.

Badan Pusat Statistik Indonesia. (2010). Profil Kriminalitas Remaja 2010. Jakarta: Katalog BPS.

Brennan, P. A., J. Hall, W. Bor, J. M. Najman, \& G. Williams. (2003). Integrating biological and social processes in relation to early-onset persistent aggression in boys and girls. Developmental Psychology, 39, 309 - 323.

Brugman, S., J. Lobbestael, A. Arntz, M. Cima, T. Schuhmann, F. Dambacher, \& A.T. Sack. (2014). Identifying Cognitive Predictors of Reactive and Proactive Aggression. Aggressive Behavior. Volume 9999, pages 1-14.

Castro, B. O. (2004). The Development of social information processing and aggressive behavior: current issues. European Journal of Developmental Psychology, 1, 87102

Guay, J.P., M. Ouimet, \& J. Proulx. (2005). On intelligence and crime: A comparison of incarcerated sex offenders and serious non-sexual violent criminals. International Journal of Law and Psychiatry, vol. 28. Elsevier Inc. All rights reserved. doi: 10.1016 / j.ijlp.2004.03.010

Huesmann, L.R., L.D. Eron, \& P.W. Yarmel. (1987). Intellectual Functioning and Aggression. Journal of Personality and Social Psychology, APA. Vol. 52.No.1, 232-240

Ijaz, S., S.F. Kazmi, \& F. Nazir. (2013). Culture As A Factor Of Intelligence Among Secondary Level Students. IOSR Journal of Research \& Method in Education (IOSRJRME) 1 (4), 40-45.

Latzman, R.D. (2009). Interrelation Among youth temperament, executive function, and externalizing behaviors. Dissertation at Iowa Research Online: http: //ir.uiowa/etd/306.

Liu, J. (2011). Early Health Risk Factors for Violence: Conceptualization, Review of the Evidence, and Implications. Aggress Violent Behav.; 16(1): 63-73. doi:10.1016/j.avb.2010.12.003.

Moffitt, T.E., W.F. Gabrielli, S.A. Mednick, \& F. Schulsinger. (1981). Socioeconomic status, IQ, and delinquency. In: Mottus, R., J. Guljajev, J. Allik, K. Laidra, \& H. Pullmann. 2011. Longitudinal associations of cognitive ability, personality traits and school grades with antisocial behavior. European Journal of Personality, 26 (1), 56-62. DOI: 10.1002 / per.820

Moshkani, M., G.A. Afrooz, \& A.A. Arjmandnia. (2015). Analytical comparison of general intelligence, verbal and practical capacities, Reviews their subscales and academic achievement of delinquent and non-delinquent youth. GMP Review, 16 (3), 317-324.

Murtiyani, N. (2011). Hubungan Pola Asuh Orang Tua dengan Kenakalan Remaja di RW V Kelurahan Sidokare Kecamatann Sidoarjo. Jurnal Keperawatan, 01(01), $1-9$.

Moshkani, M., G.A. Afrooz, \& A.A. Arjmandnia. (2015). Prediction of factors Affect deliquent behavior in deliquent and non-deliquent Adolescents. Indian Journal 
of Fundamental and Applied Life Sciences, 5 (1), 317-324. Retrieved 16 September 2015, from www.cibtech.org/sp.ed/jls/ 2015/01 / jls.htm 2015 Vol.5 (S1), pp. 5115-5124 / Moshkani et al.

Ogdon, D.P. (1996). Psychodiagnostics and Personality Assessment: A Handbook (2 ${ }^{\mathrm{nd}}$ ed.) WPS USA.

Raine, A., K. Dodge, R. Loeber, L. Gatzke-Kopp, D. Lynam, C. Reynolds, M. Stouthamer-Loeber, \& J. Liu. (2006). The Reactive-Proactive Aggression Questionnaire: Differential Correlates of Reactive and Proactive Aggression in Adolescent Boys. Aggress Behav. April 1; 32(2): 159-171. doi:10.1002/ab.20115.

Salekin, R.T. \& P.J. Frick. (2005). Psychopathy in Children and Adolescents: The need for a developmental perspective. Journal of Abnormal Child Psychology, vol. 33 no. 4. DOI: 10.1007 / s10802-005-5722-2.

Sattler, J.M. (2001). Assessment of children: cognitive application $\left(4^{r d}\right.$ ed.). San Diego: Jerome M. Sattler Publisher, inc.

Stickle, T. R., N.M. Kirkpatrick, \& L.N. Bursh. (2009). Callous-unemotional traits and social information processing: Multiple risk-factor models for understanding aggressive behavioral in antisocial youth. Law and Human Behavior, 33, 515529.

Wechsler, D. (1958). The measurement and appraisal of adult intelligence. In: Sattler, J.M. 2001. Assessment of children: cognitive application, $4{ }^{\text {rd }}$ ed (p.136). San Diego: Jerome M. Sattler Publisher, inc.

Wyhe, K. (2012). Wechsler Abbreviated Scale of Intelligence: Preliminary normative data for 12-15-year-old English- and Afrikaans-speaking Coloured learners in the Western Cape. Dissertation. Published by the University of Cape Town (UCT). https://open.uct.ac.za/bitstream/item/12279/thesis_hum_2012_van_wyhe_k.pdf?...1

Sujoko. (2011). Hubungan antara keluarga broken home, pola asuh orang tua dan interaksi teman sebaya dengan kenakalan remaja. Thesis, Universitas Muhammadiyah Surakarta. http://eprints.ums.ac.id/13181/ 